\title{
Identification of a New Heavy-Metal-Resistant Strain of Geobacillus stearothermophilus Isolated from a Hydrothermally Active Volcanic Area in Southern Italy
}

\author{
Rosanna Puopolo ${ }^{1}$, Giovanni Gallo ${ }^{1} \mathbb{D}$, Angela Mormone ${ }^{2}$, Danila Limauro ${ }^{1}{ }^{\mathbb{C}}$, \\ Patrizia Contursi ${ }^{1}$, Monica Piochi ${ }^{2} \mathbb{D}$, Simonetta Bartolucci ${ }^{1}$ (D) and Gabriella Fiorentino ${ }^{1, *(D)}$ \\ 1 Dipartimento di Biologia, Università Degli Studi di Napoli Federico II, 80139 Napoli, Italy; \\ rosanna.puopolo@unina.it (R.P.); giovanni.gallo2@unina.it (G.G.); limauro@unina.it (D.L.); \\ contursi@unina.it (P.C.); bartoluc@unina.it (S.B.) \\ 2 Istituto Nazionale di Geofisica e Vulcanologia, Sezione Osservatorio Vesuviano, 80125 Napoli, Italy; \\ angela.mormone@ingv.it (A.M.); monica.piochi@ingv.it (M.P.) \\ * Correspondence: fiogabri@unina.it
}

Received: 3 March 2020; Accepted: 13 April 2020; Published: 14 April 2020

\begin{abstract}
Microorganisms thriving in hot springs and hydrothermally active volcanic areas are dynamically involved in heavy-metal biogeochemical cycles; they have developed peculiar resistance systems to cope with such metals which nowadays can be considered among the most permanent and toxic pollutants for humans and the environment. For this reason, their exploitation is functional to unravel mechanisms of toxic-metal detoxification and to address bioremediation of heavy-metal pollution with eco-sustainable approaches. In this work, we isolated a novel strain of the thermophilic bacterium Geobacillus stearothermophilus from the solfataric mud pool in Pisciarelli, a well-known hydrothermally active zone of the Campi Flegrei volcano located near Naples in Italy, and characterized it by ribotyping, $16 \mathrm{~S}$ rRNA sequencing and mass spectrometry analyses. The minimal inhibitory concentration (MIC) toward several heavy-metal ions indicated that the novel G. stearothermophilus isolate is particularly resistant to some of them. Functional and morphological analyses suggest that it is endowed with metal resistance systems for arsenic and cadmium detoxification.
\end{abstract}

Keywords: heavy metals; thermophiles; Geobacillus stearothermophilus; minimal inhibitory concentration (MIC); transmission electron microscopy (TEM)

\section{Introduction}

Heavy metals are among the most persistent and toxic pollutants. Differently from organic xenobiotics, which can be converted into non-harmful substances, they cannot be completely removed from the environment [1]. Anthropogenic sources including mining and various industrial (vehicle emissions, lead-acid batteries, paints) and agricultural activities (fertilizers, aging water supply) lead to their increasing accumulation [2-4]. The prolonged exposure to heavy metals is responsible for several human diseases, as documented by the World Health Organization [5]. For example, arsenic and cadmium have been classified as carcinogenic compounds by the International Agency for Research on Cancer (IARC) in both humans and animals [6,7], while the exposure to lead is responsible for $3 \%$ of cerebrovascular disease worldwide [8]. Therefore, reduction of heavy-metal pollution is actually among the greatest challenges of the new century [9-11].

As a consequence of the massive accumulation of toxic metals into the environment, majority of microorganisms have developed genetic resistance mechanisms [12-14] and even specific metabolic 
pathways to deal with toxic metals [15-17]. For instance, gram-positive and gram-negative bacteria possess arsenic resistance systems encoded by operons carried either on plasmids or on the chromosome. Genetic determinants are usually the three genes $\operatorname{ars} R$, $\operatorname{ars} B$, and $\operatorname{ars} C[18,19]$, among which $\operatorname{ars} R$ encodes a trans-acting repressor of the ArsR/SmtB family involved in transcriptional regulation [20-22], arsB encodes an As(III) efflux transporter (ArsB/Acr3) [23], and arsC encodes a cytoplasmic arsenate reductase that converts $\mathrm{As}(\mathrm{V})$ to $\mathrm{As}(\mathrm{III})$, the latter extruded outside the cell [24-26]. Other organisms benefit of additional proteins that improve the arsenic resistance, such as the arsenite methyltransferases [27]. The arsenic resistance system of some microorganisms also provides Cd(II) tolerance [28-30]. Gram-positive and gram-negative bacteria also possess cadmium resistance systems, which are generally composed by two genes, $\mathrm{cadC}$ coding for a helix-turn-helix transcriptional regulator that controls the second gene cadA, coding for a cadmium-translocating P-type ATPase. The loci of genes involved in cadmium resistance are either on plasmids or on chromosomes [31].

Since many metals, such as arsenic, are naturally present in volcanic and geothermal springs, these niches are commonly colonized by heavy-metal-resistant microorganisms [32,33]; they actively participate in geochemical cycles, solubilizing and precipitating metals thus contributing to transforming the bedrock and remodeling their ecosystems [34]. The interest in the comprehension of the molecular mechanisms underlying heavy-metal resistance in microorganisms thriving in extreme environments is growing fast because of the urgent need to develop effective and eco-sustainable approaches toward heavy-metal pollution [35-38].

In this work, we describe the isolation and characterization of a new thermophilic heavy-metal-resistant microorganism from the solfataric mud pool of Pisciarelli in the Campi Flegrei volcano located near Naples in Italy. The site has extreme environmental conditions in terms of temperature, acidity, and As-rich geochemistry due to an intense hydrothermal activity $[39,40]$.

\section{Materials and Methods}

\subsection{Chemicals}

The antibiotics and metal salts used in this work were purchased by Sigma-Aldrich. Antibiotics, identified through the unique number assigned by the Chemical Abstracts Service (CAS), are: Ampicillin (CAS number: 7177-48-2); bleomycin sulfate (CAS number: 9041-93-4); chloramphenicol (CAS number: 56-75-7); kanamycin sulfate (CAS number: 70560-51-9); hygromycin B (CAS number: 31282-04-9); tetracycline (CAS number: 60-54-8). Metal salts used are the following: sodium (meta)arsenite $\left(\mathrm{NaAsO}_{2}\right)$; sodium arsenate dibasic heptahydrate $\left(\mathrm{Na}_{2} \mathrm{HAsO}_{4} \cdot 7 \mathrm{H}_{2} \mathrm{O}\right)$; cadmium chloride $\left(\mathrm{CdCl}_{2}\right)$; cobalt chloride hexahydrate $\left(\mathrm{CoCl}_{2} \cdot 6 \mathrm{H}_{2} \mathrm{O}\right)$; cobalt chloride $\left(\mathrm{CoCl}_{3}\right)$; chromium oxide $\left(\mathrm{CrO}_{3}\right)$; copper nitrate trihydrate $\left[\mathrm{Cu}\left(\mathrm{NO}_{3}\right)_{2} \cdot 3 \mathrm{H}_{2} \mathrm{O}\right]$; mercury chloride, $\left(\mathrm{HgCl}_{2}\right)$; nickel chloride $\left(\mathrm{NiCl}_{2}\right)$; sodium orthovanadate dihydrate $\left(\mathrm{Na}_{3} \mathrm{VO}_{4} \cdot 2 \mathrm{H}_{2} \mathrm{O}\right)$.

\subsection{Strain Isolation and Molecular Identification}

Soil samples were collected in April 2016 at the hydrothermal site of Pisciarelli (Figure 1) that lies on the Solfatara volcano, one of the various eruptive vents generated within the wide volcanic field of the Campi Flegrei since ca. 4100 years [41].

The materials were aseptically sampled from the main mud pool; both $\mathrm{pH}$ and temperature were measured contextually by indicator papers and a Fluke digital thermocouple probe, respectively. The water was collected from the bubbling mud pool, while the mud was taken from its marginal water-poorer portion (Figure 1). Temperature and $\mathrm{pH}$ values were $94.3^{\circ} \mathrm{C}$ and 4.8 in the bubbling mud pool, respectively, while in the marginal water-poorer portion they were $55.3^{\circ} \mathrm{C}$ and 6.0 , respectively. The local levels of arsenic are in the 10-20 ppm range [39]. 


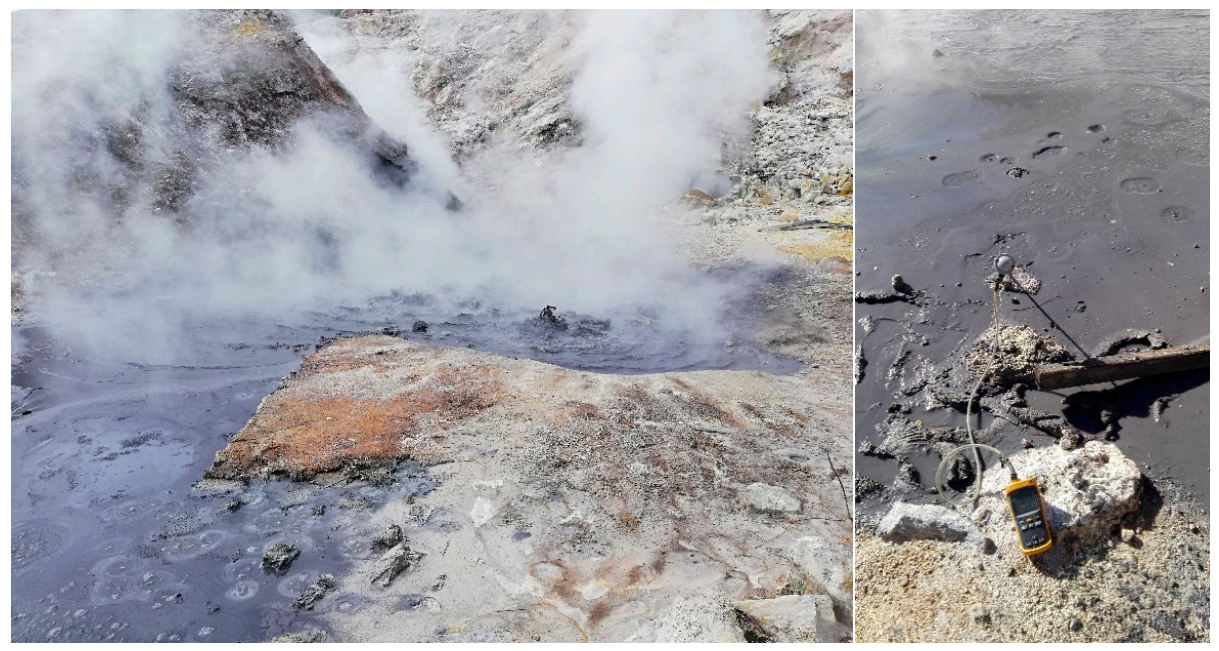

Figure 1. Pisciarelli sampling site showing an intense hydrothermal activity and the puddle water (left) and mud (right) collected.

Enrichment cultures were set in $50 \mathrm{~mL}$ tubes with $20 \mathrm{~mL}$ of Luria-Bertani (LB) medium [42] and inoculated with $1 \mathrm{~g}$ of soil sample at 37,50 , and $75^{\circ} \mathrm{C}$ for $24 \mathrm{~h}$. Then serial dilutions of these culture samples were streaked on LB-agar plates $(1.5 \%)$ at the same temperature values for $24 \mathrm{~h}$. Bacterial colonies were found in the mud sample incubated at $50^{\circ} \mathrm{C}$ and the isolation of a pure strain was carried out by repeated streak plating on solid medium prepared with the LB-agar incubated at $50^{\circ} \mathrm{C}$.

To identify the new isolate, we used different approaches based on standard procedures such as automated ribotyping on digested chromosomal DNA and fatty acid analysis [43]. Since the taxonomic identification at the species level could not be determined with ribotyping data, a MALDI-TOF MS analysis (i.e., Matrix-Assisted Laser Desorption/Ionization Mass Spectrometry performed with a Time-Of-Flight Mass Spectrometer) was also commissioned to the Leibniz Institute DSMZ (the German Collection of Microorganisms and Cell Cultures, $\mathrm{GmbH}$ ). Sample preparation and instrumental conditions have been described elsewhere [44]. The identification report was generated by the Biotyper software (version 3.1, Bruker Daltonics GmbH, Bremen, Germany) and the strain was identified as Geobacillus stearothermophilus with a score corresponding to high probable strain identification (higher than 2.3).

Moreover, $16 \mathrm{~S}$ rRNA sequencing was commissioned to Eurofins. The resulting sequencing data (about $1000 \mathrm{nt}$ ) were analyzed in the nucleotide database of the U.S. National Center for Biotechnology Information (NCBI, www.ncbi.nlm.nih.gov). The sequence in the sample could be identified as a novel strain of Geobacillus stearothermophilus (G. stearothermophilus GF16 hereafter). It was also submitted to GenBank and the accession number is MT311361.

Neighbor-Joining Tree Development

In order to obtain information about evolutionary relationships within G. stearothermophilus species, the 16S rRNA sequence of the novel G. stearothermophilus GF16 isolate was analyzed with BLASTn; sequences with identities from $99 \%$ to $97 \%$ were aligned using the multiple sequence alignment tool CLUSTAL Omega (https://www.ebi.ac.uk/Tools/msa/clustalo/). Finally, a neighbor-joining tree was constructed using the default option of ClustalW2 (Simple Phylogeny) [45].

\subsection{Geobacillus stearothermophilus Physiological Analyses}

\subsubsection{Determination of Optimal Growth Conditions}

A frozen $\left(-80^{\circ} \mathrm{C}\right)$ glycerol-stock of $\mathrm{G}$. stearothermophilus GF16 was streaked on an LB-agar plate and incubated overnight at $50^{\circ} \mathrm{C}$. Single colonies that appeared on the plate were inoculated into liquid 
LB media at different $\mathrm{pH}$ values ( $\mathrm{pH} 3, \mathrm{pH} 5, \mathrm{pH} 7)$ at 50 and $60{ }^{\circ} \mathrm{C}$ under shaking. Growth was only observed at $\mathrm{pH} 7.0$, whereas the optimal growth temperature turned out to be $60{ }^{\circ} \mathrm{C}$. The generation time $(G)$ was calculated with the following formula: $G=t / n$, where $t$ is the time interval and $n$ the number of generations ( $t$ is considered to be between 3 and $4 \mathrm{~h}$, in the exponential phase). All the experiments were repeated in triplicate.

\subsubsection{Antibiotic Susceptibility}

For the determination of minimal inhibitory concentrations (MIC) toward antibiotics, a modified version of a protocol described in the Manual of Antimicrobial Susceptibility Testing was followed [46]. In detail, a frozen $\left(-80^{\circ} \mathrm{C}\right)$ stock of $G$. stearothermophilus GF16 was streaked on an LB-agar plate and incubated at $60{ }^{\circ} \mathrm{C}$ overnight. A single colony was inoculated into liquid LB medium and incubated at $60{ }^{\circ} \mathrm{C}$ under shaking up to the exponential phase corresponding to Optical Density (OD) at $600 \mathrm{~nm}$ of 1.5 $\left(\mathrm{OD}_{600 \mathrm{~nm}}\right.$ were measured in a Varian Cary 50 Scan UV-Visible Spectrophotometer). Then the bacterial culture was diluted up to $0.1 \mathrm{OD}_{600 \mathrm{~nm}}$ in LB medium supplemented with increasing concentrations (from 5 to $50 \mu \mathrm{g} / \mathrm{mL}$ ) of antibiotics (ampicillin, kanamycin, chloramphenicol, tetracycline, hygromycin, and bleomycin) and grown at $60{ }^{\circ} \mathrm{C}$ for $16 \mathrm{~h}$; for each determination, three independent experiments were carried out in triplicate. Minimum inhibitory concentration (MIC) was determined as the lowest concentration of antibiotics that completely inhibited the growth of the strain as evaluated by $\mathrm{OD}_{600 \mathrm{~nm}}$ measurements after incubation for $16 \mathrm{~h}$ under optimal growth conditions.

\subsubsection{Heavy-Metal Resistance}

For the determination of MIC toward heavy-metal ions (As(V), As(III), Cd(II), Co(III), Cr(VI), $\mathrm{Cu}(\mathrm{II}), \mathrm{Hg}(\mathrm{II}), \mathrm{Ni}(\mathrm{II}), \mathrm{V}(\mathrm{V}))$, cell cultures were grown and diluted as described above. The heavy metals were added at increasing concentration ranging from 0.1 to $120 \mathrm{mM}$. The MIC values were determined as described above. The values reported are the average of three independent experiments each one performed in triplicate.

\subsubsection{Evaluation of $\mathrm{As}(\mathrm{V})$ Biotransformation}

The As(V) transformation capacity of G. stearothermophilus GF16 to produce As(III) was qualitatively evaluated using a colorimetric assay based on the formation of precipitates upon reaction of $\mathrm{AgNO}_{3}$ with arsenic [47]. A single colony was cultured in LB liquid medium at $60{ }^{\circ} \mathrm{C}$ up to $1.0 \mathrm{OD}_{600 \mathrm{~nm}}$; then an aliquot of the cell suspension was streaked on LB-agar plates containing $50 \mathrm{mM}$ sodium arsenate $\left(\mathrm{Na}_{2} \mathrm{HAsO}_{4}\right)$. The LB-agar plates were incubated at $60^{\circ} \mathrm{C}$ for $18 \mathrm{~h}$ and then flooded with $0.1 \mathrm{M} \mathrm{AgNO}_{3}$. As controls, the following plates were prepared: (1) LB agar supplemented with As(V), without cells; (2) LB agar, without As(V), with streaked cells; (3) LB agar without either cells or As(V). The color of the precipitate on each plate was compared to a color scale, which could be used as reference to distinguish by eye different ratios of $\mathrm{As}(\mathrm{V}) / \mathrm{As}(\mathrm{III})$, thus allowing a qualitative evaluation of $\mathrm{As}(\mathrm{III})$ production. The reference color scale was developed by mixing defined ratios of As(V) and As(III) in different tubes. The final concentration of total arsenic was $50 \mathrm{mM}$ for all the samples. All the experiments were repeated in triplicate.

\subsubsection{Bioinformatic Analysis}

Bioinformatic analyses were performed to evaluate the presence of arsenic and/or cadmium resistance genes in the genomes of the following three sequenced strains of G. stearothermophilus: (a) strain $\mathrm{n}^{\circ} 10$ (Accession BioProject PRJNA252389); (b) strain DSM 458 (Accession BioProject PRJNA327158); (c) strain B5 (Accession Bioproject PRJNA513473). Loci containing sequences coding for putative arsenic resistance proteins were identified on the NCBI database, and the corresponding translated sequences were aligned with the multiple sequence alignment program Clustal Omega (https://www.ebi.ac.uk/Tools/msa/clustalo/). 


\subsubsection{Transmission Electron Microscopy (TEM)}

To analyze cell morphology, G. stearothermophilus GF16 was grown at $60{ }^{\circ} \mathrm{C}$ in LB medium (pH 7), and in LB (pH 7) supplemented with As(V) $117 \mathrm{mM}$ or Cd(II) $0.9 \mathrm{mM}$ for $16 \mathrm{~h}$; a control grown in the absence of heavy-metal ions was also harvested at $1.5 \mathrm{OD}_{600 \mathrm{~nm}}$ corresponding to a mid-exponential growth phase. Cells were pelleted by centrifugation, washed twice with phosphate buffered saline (PBS 1\%), and fixed as reported by Pinho et al. [48]. Resi-sections were prepared with the ultramicrotome (LKB SuperNova) and serially stained with uranyl acetate and lead citrate. The sections were then studied on a Philips EM 208s Transmission Electron Microscope. Control cells not subjected to metal treatment were compared with heavy-metal-treated samples to check for possible heavy-metal accumulation.

\section{Results and Discussion}

\subsection{Geochemical Characterization of the Sampling Site}

Like similar volcanic systems worldwide, the Solfatara volcano hosts an acidic sulfate environment determined by the hot circulation of aggressive sulfurous fluids deriving from mixing between deeply infiltrating meteoric waters and ascending magmatic gases [39-41]. This phenomenon causes intense rock alteration and concentration of certain elements, such as As [39,49-54]. However, differently from the diffuse and fumarolic outgassing characterizing the Solfatara crater, the Pisciarelli site is a water-dominant environment, showing the formation of boiling pools and water springs and the opening of low-energetic geyser-type vents. The site represents the shallowest portion of a widespread geothermal system that develops in the subsurface and converts into brines downward to its deeper roots that are directly supplied by the magmatic outgas. Due to the increased hydrothermal activity since 2006, the site shows maximum temperatures of ca. $110^{\circ} \mathrm{C}$ and up to 260 tons/day of $\mathrm{CO}_{2}$ [55] with an abundance of $\mathrm{H}_{2} \mathrm{~S}$ and the presence of minor gaseous species such as $\mathrm{CH}_{4}, \mathrm{~N}_{2}, \mathrm{H}_{2}$, and $\mathrm{CO}$.

At the time of sampling, the bubbling mud pool was at $\mathrm{pH} 4.8$ and $94.3^{\circ} \mathrm{C}$ and the marginal mud at $\mathrm{pH} 6.0$ and $55.3^{\circ} \mathrm{C}$, while surrounding soils were at temperature up to $98-99^{\circ} \mathrm{C}$ and very acidic $\mathrm{pH}$. These values are in the range known for the area, although lower temperatures were also measured in the mud pool (approximately $70^{\circ} \mathrm{C}$ ). Furthermore, the mineralogical and chemical features of the sampled materials [39] are those usually determined. Indeed, the mud was typically gray in color and essentially enclosed sulfates (i.e., K- and Al- bearing alunite), sulfides (i.e., Fe- plus S-bearing pyrite), and silica-phases; dried water samples crystallized $\mathrm{NH}_{4}$-bearing sulfates. The mud is enriched in $\mathrm{As}$ (10-20 ppm) and $\mathrm{Hg}$ (around $40 \mathrm{ppm}$ ) compared to the protolith volcanic deposits; contains few wt.\% of $\mathrm{Fe}_{2} \mathrm{O}_{3}$; approximately 60 ppm of $\mathrm{V}$; 10-20 ppm of $\mathrm{Pb}$; $<10$ ppm of $\mathrm{Co}, \mathrm{Ni}$, and $\mathrm{Cr} ; 10-20 \mathrm{ppm}$ of $\mathrm{Cu}$; $1-2$ ppm of Tl; and practically lacks $C d$ being at $<0.1$ ppm [39]. Based on Valentino and Stanzione [56], Pisciarelli waters are rich in $\mathrm{SO}_{4}{ }^{-2}(1400-7000 \mathrm{mg} / \mathrm{L})$ and $\left.\mathrm{NH}_{4} 500-1000 \mathrm{mg} / \mathrm{L}\right)$; contain $\mathrm{F}(0.5-30 \mathrm{mg} / \mathrm{L})$, $\mathrm{Al}(65-20 \mathrm{mg} / \mathrm{L})$, and B (0.1-0.8 mg/L); lack carbonate species and chlorine; the content of As, $\mathrm{Hg}$, $\mathrm{Tl}$, $\mathrm{Pb}$ is approximately $40-2000,40-250,2-8$, and 5-30 $\mu \mathrm{g} / \mathrm{L}$, respectively. The general enrichment in S, $\mathrm{NH}_{4}$, As, and $\mathrm{Hg}$ is consistent with the volcanic setting and the magmatic/geothermal outgas support. According to Aiuppa et al. [54], arsenate is the As-compost under equilibrium in the water solutions.

\subsection{Isolation and Identification of Geobacillus stearothermophilus GF16}

Upon incubation of mud samples taken from the marginal water-poorer portion, cell growth was observed in LB medium at $\mathrm{pH} 7$ and $50^{\circ} \mathrm{C}$. Single colonies were isolated by serial dilutions in the same medium, and the isolated strain showed an optimal growth temperature of $60^{\circ} \mathrm{C}$.

In order to identify the microorganism, ribotyping and fatty acid analyses were performed at DSMZ; the results led to the identification of a member of Geobacillus genus but did not allow to differentiate unambiguously at species level. Geobacilli were first described by Nazina et al. in 2001 [57]; they are gram-positive, endospore-forming, aerobic or facultative anaerobic thermophiles, growing optimally at temperatures between 50 and $72{ }^{\circ} \mathrm{C}$ and exploitable for various biotechnological 
applications such as for bioremediation and production of thermostable enzymes and biofuels [58,59]. The interest toward microorganisms of the Geobacillus genus prompted us to combine two different experimental approaches such as MALDI-TOF MS analysis and 16S rRNA sequencing to try to unambiguously identify the species. Indeed, the classification of the different species within the Geobacillus genus is challenging since the sequence similarity of the $16 \mathrm{~S}$ rRNA can be higher than 97\% even among species [60]. On the other hand, MALDI-TOF MS analysis has been proposed as a powerful bioanalytical method to detect profiles of proteins derived from whole bacterial cells to be used for bacteria identification [61]. The combined molecular approaches allowed the identification of a new isolate of Geobacillus stearothermophilus that we named G. stearothermophilus GF16.

Multiple alignment of $16 \mathrm{~S}$ rRNA sequence of the novel G. stearothermophilus isolate (GF16) with those of other Geobacilli and Bacilli with identities from 99\% to 97\% was performed to build the phylogenetic tree shown in Figure 2. The results confirmed the difficulty in determining a threshold for defining species within the Geobacillus genus and supported the concept that a combination of genotypic and phenotypic characteristics could be not sufficient for describing a new species [60].

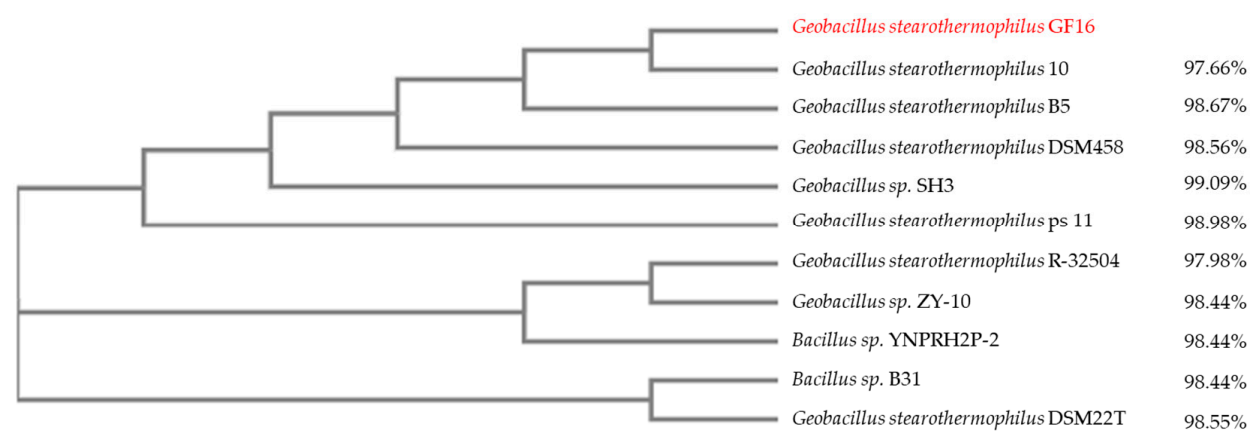

Figure 2. Schematic representation of a phylogenetic tree based on $16 \mathrm{~S}$ rRNA sequences of different Geobacillus stearothermophilus strains. This is a neighbor-joining tree without distance corrections. The new isolate is highlighted in red. The sequence identity (\%) to G. stearothermophilus GF16 is reported on the right.

\subsection{Metal Ion Resistance and Antibiotic Susceptibility in G. stearothermophilus GF16}

To evaluate the sensitivity and the tolerance of G. stearothermophilus GF16, MICs toward different antibiotics and heavy metals were determined. For this purpose, the microorganism was grown in the presence of different heavy metals (see Table 1) and antibiotics (ampicillin, kanamycin, chloramphenicol, tetracycline, hygromycin, bleomycin). G. stearothermophilus GF16 was found to be sensitive to all the tested antibiotics, even at the lowest concentration used; to the best of our knowledge, no antibiotic resistance has been previously reported for other G. stearothermophilus isolates, although the genome of G. stearothermophilus 10 contains a sequence coding for a putative tetracycline MFS (Major Facilitator Superfamily) efflux protein (locus tag: GT50_RS17520).

Table 1. G. stearothermophilus resistance to heavy-metal ions.

\begin{tabular}{ccc}
\hline Metal Ions & $\mathbf{m M}$ & \pm \\
\hline $\mathrm{As}(\mathrm{III})$ & 1.90 & 0.10 \\
$\mathrm{As}(\mathrm{V})$ & 117 & 3.00 \\
$\mathrm{Cd}(\mathrm{II})$ & 0.90 & 0.10 \\
$\mathrm{Co}(\mathrm{II})$ & 2.00 & 0.50 \\
$\mathrm{Co}(\mathrm{III})$ & 2.75 & 0.25 \\
$\mathrm{Cr}(\mathrm{VI})$ & 0.25 & 0.01 \\
$\mathrm{Cu}(\mathrm{II})$ & 4.10 & 0.10 \\
$\mathrm{Hg}(\mathrm{II})$ & 0.02 & 0.00 \\
$\mathrm{Ni}(\mathrm{II})$ & 1.30 & 0.10 \\
$\mathrm{~V}(\mathrm{~V})$ & 128 & 2.00 \\
\hline
\end{tabular}


Interestingly, G. stearothermophilus showed high tolerance to $\mathrm{As}(\mathrm{V})$ and $\mathrm{V}(\mathrm{V})$, as reported in Table 1 . Similar MIC values were also found in other Geobacilli such as G. stearothermophilus AGH-02 [62], G. stearothermophilus ASR4 [63], or Geobacillus kaustophilus [64]. The high resistance to both vanadate and arsenate ions was not surprising considering the similarity in their structures; in addition, the structural similarity of both ions with the phosphate ions suggested that $\mathrm{V}(\mathrm{V})$ and $\mathrm{As}(\mathrm{V})$ could be taken up by cells through phosphate transport systems [65].

As for other aerobic microorganisms [66], arsenic resistance within the Geobacillus genus relies on the ability to oxidize arsenite, or to reduce arsenate and extrude the arsenite. In particular, As(III) resistance depend on membrane or periplasmatic oxidase activities [67], while resistance to As(V) mainly involves intracellular reductase activities [68] and membrane transporters for As(III) efflux [69]. Since we measured very low tolerance to As(III) (Table 1) in comparison to the values reported in the literature (1.9 mM versus 10-30 mM) [62-64], it can be hypothesized either that our isolate lacks arsenite oxidase activity or that the high sensitivity to As(III) is due to the absence of active transport systems for As(III) efflux. For example, the legume symbiont Sinorhizobium meliloti was very tolerant to $\mathrm{As}(\mathrm{V})$ but very sensitive to As(III) since it was deficient of As(III) transporter systems [65,70].

The new isolate was also found to be Cd(II) tolerant, and in this case the MIC value determined was similar to that measured in other Geobacilli (ranging from 0.4 to $3.2 \mathrm{mM}$ ) [71]. For the majority of these microorganisms $\mathrm{Cd}$ (II) resistance was ascribed to biosorption, i.e., a phenomenon of metal binding to the microbial cell wall, which does not involve energy consumption [72,73]. Interestingly, the Pisciarelli site is enriched in arsenic and vanadium but lacks cadmium (see Section 3.1). Therefore, the presence of genetic determinants for $\mathrm{Cd}(\mathrm{II})$ tolerance cannot be traced back to the selective pressure exerted by the environment.

Figure 3 shows the effect of $\mathrm{As}(\mathrm{V})$ on G. stearothermophilus GF16 growth: the generation time shifted from $30 \mathrm{~min}$ for cells grown in the absence of $\mathrm{As}(\mathrm{V})$ to 60 and $125 \mathrm{~min}$ for those grown in the presence of $\mathrm{As}(\mathrm{V}) 25$ and $50 \mathrm{mM}$, respectively.

As we only observed a high $\mathrm{As}(\mathrm{V})$ resistance, we sought to evaluate whether G. stearothermophilus GF16 had any $\mathrm{As}(\mathrm{V})$ reductase activity; for this purpose, an $\mathrm{AgNO}_{3}$ colorimetric method $[47,74-76]$ was employed on cells grown on LB-agar supplemented with $\mathrm{As}(\mathrm{V})$, using as controls plates of: (1) LB-agar with $\mathrm{As}(\mathrm{V})$ and no cells; (2) LB-agar without $\mathrm{As}(\mathrm{V})$ and with grown cells; (3) LB-agar without cells and $\mathrm{As}(\mathrm{V})$ (Figure 4). The method is based on the formation of colored precipitates upon reaction of $\mathrm{AgNO}_{3}$ with arsenic; in particular, the addition of $\mathrm{AgNO}_{3}$ to the grown cells produces a brown precipitate $\left(\mathrm{Ag}_{3} \mathrm{AsO}_{4}\right)$ if $\mathrm{AgNO}_{3}$ reacts with $\mathrm{As}(\mathrm{V})$ and a bright yellow precipitate $\left(\mathrm{Ag}_{3} \mathrm{AsO}_{3}\right)$ if $\mathrm{AgNO}_{3}$ reacts with $\mathrm{As}(\mathrm{III})[47,74-76]$. Therefore, the addition of $\mathrm{As}(\mathrm{V})$ to the growth medium implies that $\mathrm{As}(\mathrm{III})$ can be revealed only if it is produced inside the cell and extruded afterward. Moreover, as can be seen from the reference color scale in Figure 4E, the solution is clearly yellow only when $\mathrm{As}(\mathrm{III})$ is more than $50 \%$ of the total arsenic. Figure $4 \mathrm{~A}$ shows a brown precipitate, indicating that $\mathrm{As}(\mathrm{V})$ was the predominant chemical species outside the cells. The negligible amount of extracellular As(III) detected within this experiment, suggested either that G. stearothermophilus GF16 had low As(V) reductase activity or could not efficiently extrude As(III). This latter hypothesis might be consistent with the lack or low activity of As(III) efflux systems. However, to confirm these hypotheses, more sensitive experimental approaches such as Inductively Coupled Plasma Mass Spectrometry (ICP-MS), able to detect lower amounts of As(III), are required.

\subsection{Bionformatic Analyses}

To the best of our knowledge, the genomes of only three strains of G. stearothermophilus GF16 have been fully sequenced (Table 2): (1) strain "10" isolated from the Yellowstone hot spring (USA); (2) strain "DSM458" isolated from a sugar beet factory in Austria [77]; and (3) strain "B5" isolated from a rice stack in China. As shown in the phylogenetic tree, these strains are evolutionarily very closely related to the GF16 isolate (Figure 2). 


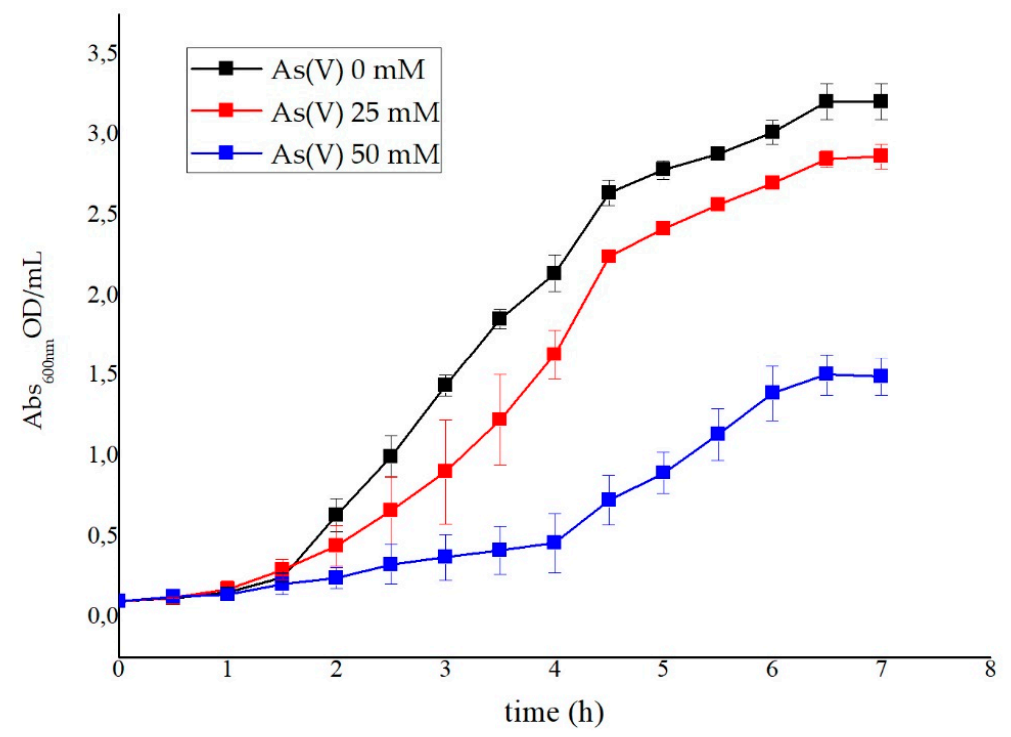

Figure 3. G. stearothermophilus GF16 grown in the presence and absence of As(V).
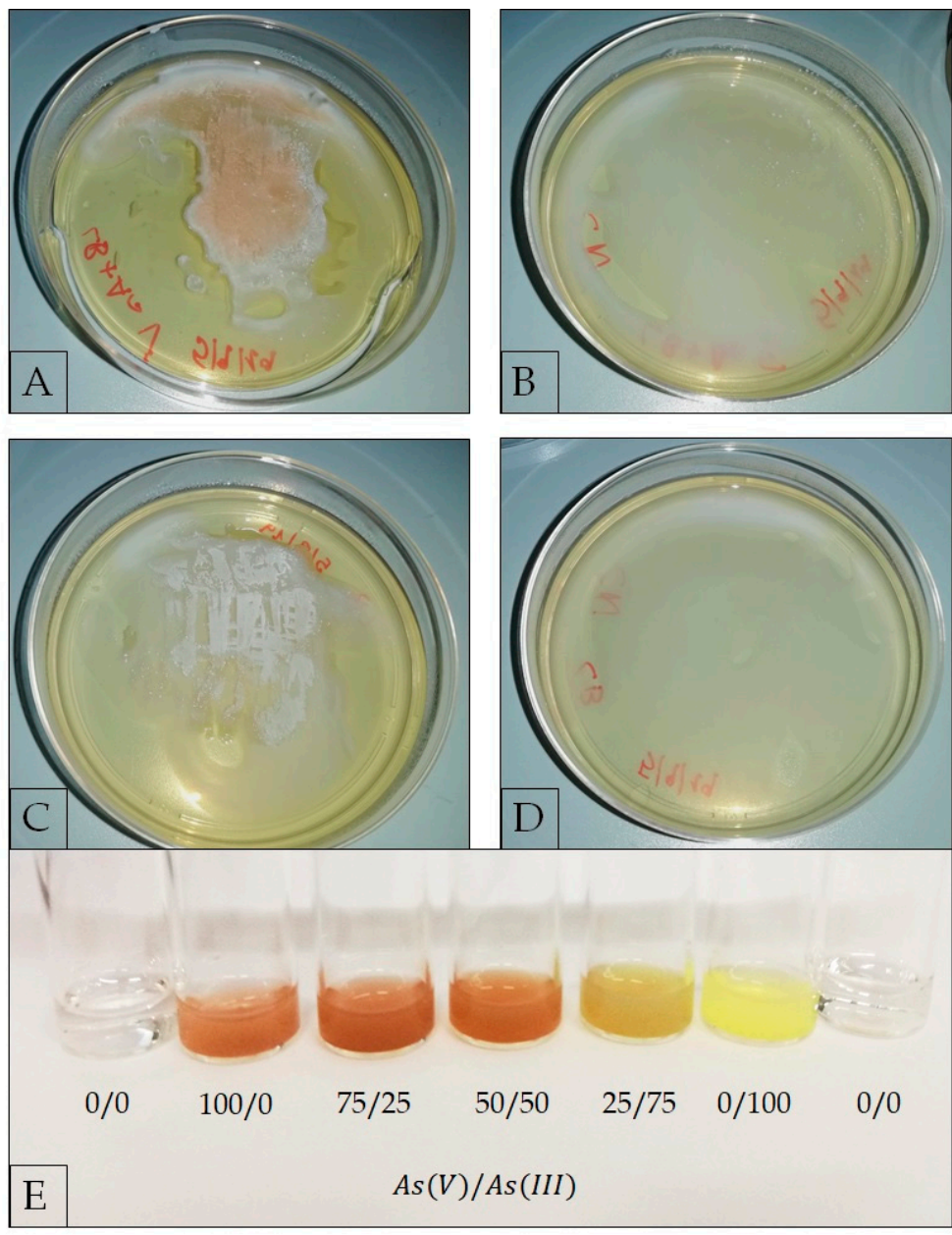

Figure 4. Silver nitrate test on: (A) G. stearothermophilus GF16 grown on LB-agar plate supplemented with $50 \mathrm{mM} \mathrm{As}(\mathrm{V})$; (B) LB-agar plate supplemented with $50 \mathrm{mM} \mathrm{As}(\mathrm{V})$ (control 1); (C) G. stearothermophilus grown on LB-agar plate (control 2); (D) LB-agar plate (control 3). (E) Determination of precipitate color as function of $\mathrm{As}(\mathrm{V}) / \mathrm{As}(\mathrm{III})$ ratio (\%). The concentration of total arsenic in solution in each sample is $50 \mathrm{mM}$ (i.e., for the ratio 50/50 there are in solution $\mathrm{As}(\mathrm{V}) 25 \mathrm{mM}$ and $\mathrm{As}(\mathrm{III}) 25 \mathrm{mM}$ ). 
Table 2. List of G. stearothermophilus strains with sequenced genomes, as reported in the National Center for Biotechnology Information (NCBI) genome databank.

\begin{tabular}{|c|c|c|c|c|c|c|c|}
\hline Organism & Strain & Origin & Genome Size (Mb) & CG\% & Gene & Protein & BioProject \\
\hline Geobacillus stearothermophilus & 10 & Yellowstone thermal spring & 3.67 & 52.61 & 3645 & 3312 & PRJNA252389 \\
\hline Geobacillus stearothermophilus & DSM458 & Austria sugar beet factory & 3.46 & 52.10 & 3683 & 3165 & PRJNA327158 \\
\hline Geobacillus stearothermophilus & B5 & China rice stack & 3.39 & 52.50 & 3426 & 3045 & PRJNA513473 \\
\hline
\end{tabular}

In order to verify whether different strains of G. stearothermophilus had arsenic and cadmium resistance systems and to understand whether such systems were conserved among the species, a comparative genomic analysis was carried out on the sequences of three G. stearothermophilus genomes available at NCBI (Table 2). The study revealed differences in the abundance and type of putative arsenic and cadmium resistance genes in the genomes analyzed (Table 3). In particular, all of them contained one conserved copy of $c a d C$ and $c a d A$ : the alignment of the corresponding proteins from the three different strains showed a high degree of identity $(92 \%)$. This result could explain the tolerance of the new isolate toward Cd(II) despite the absence of this metal within its specific environment (see Section 3.1). Regarding arsenic resistance systems, a copy of ArsB/Acr3 arsenite efflux transporters was found in each genome, whereas at least a simple ars system encoding the arsenate reductase (arsC) in tandem with an ArsR/SmtB transcriptional regulator was found only in the genomes of G. stearothermophilus 10 and B5 strains ( $86 \%$ of identity of both proteins). On the other hand, the strain DSM458 encoded a unique arsenate reductase; moreover, sequences coding for putative arsenite oxidases were not observed in any of the genomes analyzed $[78,79]$. To the best of our knowledge there are no reports of functional studies on metal resistance systems in these three strains, therefore we conclude that additional investigation is required to shed light on the occurrence of common metal resistance mechanisms in G. stearothermophilus isolates. However, the in silico analysis of the genomes showed that the number and type of genes coding for elements involved in arsenic resistance is variable within the same species and depends on the specific evolutionary adaptation of that particular strain [80].

Table 3. List of putative genes for As and Cd(II) resistance in G. stearothermophilus strains.

\begin{tabular}{|c|c|c|c|}
\hline & $\begin{array}{c}\text { Geobacillus stearothermophilus } 10 \\
\text { (PRJNA252389) }\end{array}$ & $\begin{array}{l}\text { Geobacillus stearothermophilus DSM458 } \\
\text { (PRJNA327158) }\end{array}$ & $\begin{array}{c}\text { Geobacillus stearothermophilus B5 } \\
\text { (PRJNA513473) }\end{array}$ \\
\hline $\begin{array}{l}\text { Putative } \\
\text { Proteins }\end{array}$ & Locus & Locus & Locus \\
\hline ArsR & GT50_RS07590 & & $\begin{array}{l}\text { EPB69_RS07030 } \\
\text { EPB69_RS15665 } \\
\text { EPB69_RS15730 }\end{array}$ \\
\hline ArsB & GT50_RS07510 & GS458_RS16835 & EPB69_RS15660 \\
\hline ArsC & $\begin{array}{l}\text { GT50_RS07505 } \\
\text { GT50_RS06280 }\end{array}$ & $\begin{array}{l}\text { GS458_RS16830 } \\
\text { GS458_RS15800 }\end{array}$ & EPB69_RS15655 \\
\hline CadA & GT50_RS12470 & GS458_RS03700 & EPB69_RS03440 \\
\hline CadC & GT50_RS12465 & GS458_RS03695 & EPB69_RS03435 \\
\hline
\end{tabular}

\subsection{Analysis of Cellular Morphology}

In order to better define G. stearothermophilus GF16 morphology, we resolved to analyze cells through TEM. As shown in Figure 5, cells have a typical bacillar rod shape when they are actively growing.

Moreover, with the aim of verifying whether $\mathrm{As}(\mathrm{V})$ and $\mathrm{Cd}(\mathrm{II})$ had any effect on cell morphology, TEM images were also acquired on samples of G. stearothermophilus GF16 grown for $16 \mathrm{~h}$ in the presence of $\mathrm{As}(\mathrm{V})$ and $\mathrm{Cd}(\mathrm{II})$ at concentrations corresponding to the MIC values, and they were compared to images of control cells not subjected to any treatment with heavy metal (Figure 6). The sections obtained revealed the structure of the cell more clearly in the control cells (Figure 6A) than in those treated with heavy metals. However, the presence of several cells in division suggested that both $\mathrm{As}(\mathrm{V})$ and Cd(II) did not cause significant changes in the cellular structure and cell viability (of Figure 6B vs. 
Figure 6C). Nevertheless, it appeared that the cell wall of G. stearothermophilus GF16 was influenced by handling both As and Cd. In particular, the cell wall of G. stearothermophilus GF16 treated with $\mathrm{As}(\mathrm{V})$ (Figure $6 \mathrm{~B}$ ) exhibited abundance of ridges and grooves that can be related to a reduction in cell permeability. Interestingly, Cd(II)-treated cells (Figure 6C) appeared darker; this phenomenon could be ascribed to the ability of G. stearothermophilus to adsorb Cd(II), as also reported by Hetzer et al. [71].

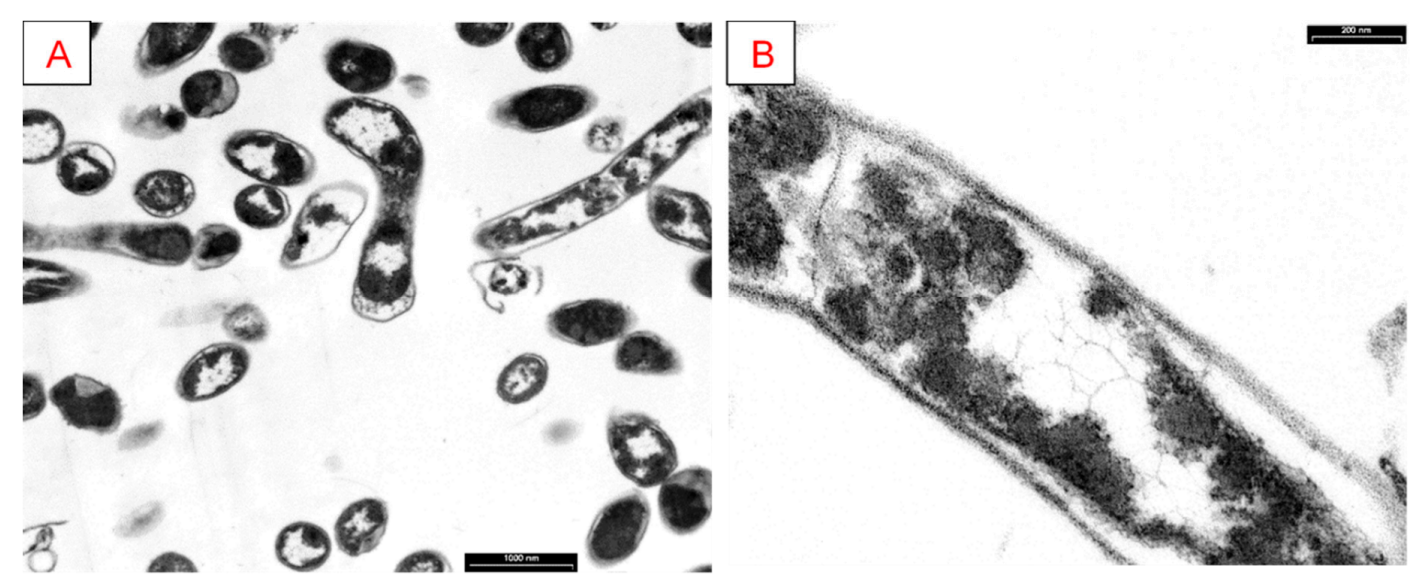

Figure 5. TEM images of G. stearothermophilus GF16 in exponential phase at different scales (black bars): (A) $1000 \mathrm{~nm}$; (B) $200 \mathrm{~nm}$.
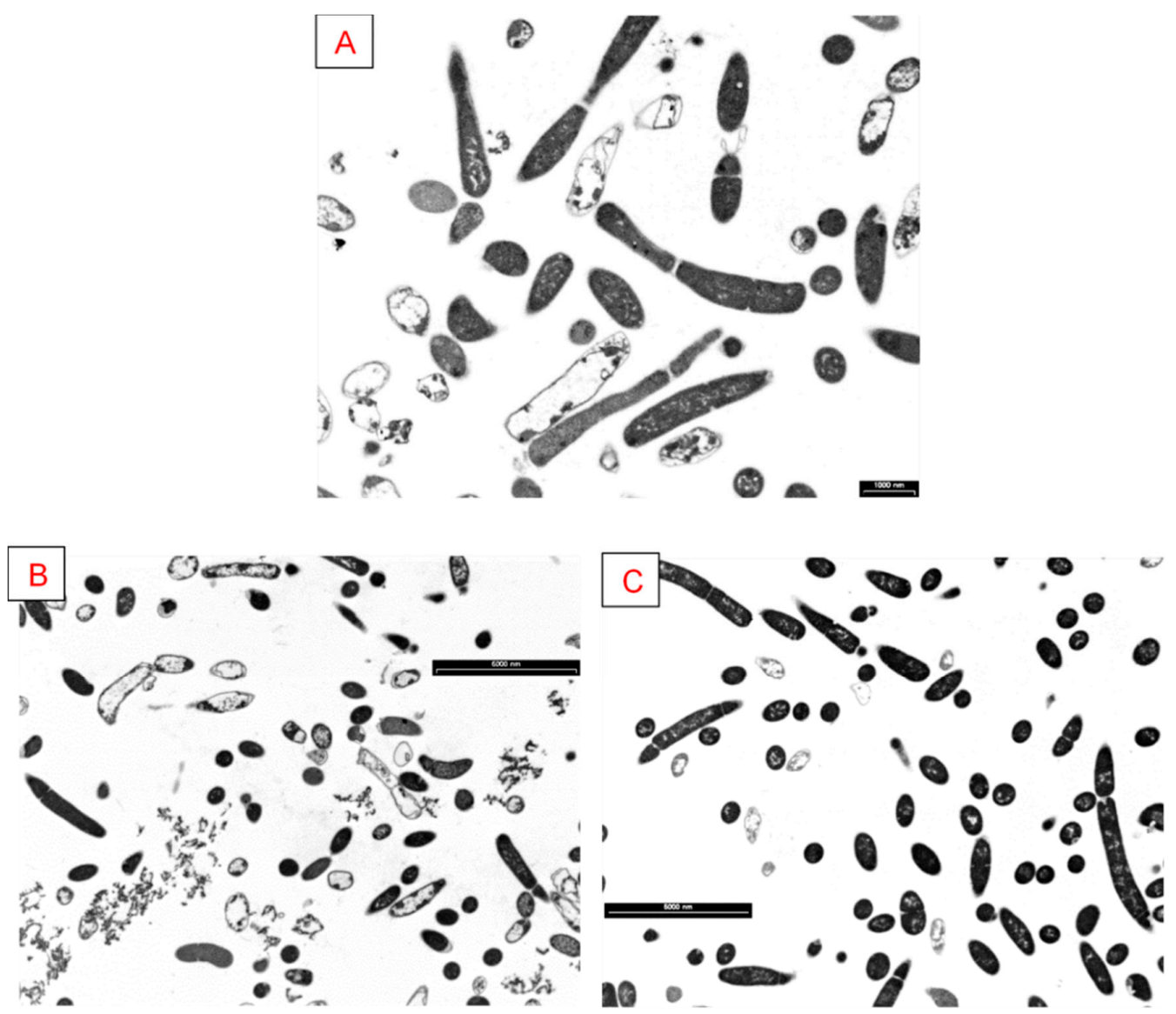

Figure 6. TEM images of G. stearothermophilus GF16: after overnight growth (A), in the presence of $\mathrm{As}(\mathrm{V})(\mathbf{B})$ and $\mathrm{Cd}(\mathrm{II})(\mathrm{C})$ at their respective MIC values. Scale: $1000 \mathrm{~nm}$ in A, elsewhere $6000 \mathrm{~nm}$. 
In conclusion, electron microscopy analyses highlighted that the cell shape/structure of G. stearothermophilus GF16 changes in presence of $\mathrm{As}(\mathrm{V})$ and $\mathrm{Cd}(\mathrm{II})$, thus suppling a morphological explanation for the tolerance of the new isolate toward these metal ions.

\section{Conclusions}

With the aim of characterizing new thermophilic heavy-metal-resistant microorganisms, soil sampling was performed in a hydrothermal volcanic area near Naples in Italy, known as Pisciarelli. This is an acidic sulfate area located close to the Solfatara crater famous for an intense endogenous diffuse and fumarolic water-dominant outgassing activity; the chemical composition of mud and water samples revealed that the main metal is iron, but arsenate is an additional significant component. Since geothermal sites are very interesting sources of thermophilic organisms and Pisciarelli is an arsenic-rich area, we hypothesized that novel thermophiles could be found able to detoxify this metal or use it for energy-yielding reactions. We succeeded in isolating a microorganism with an optimal growth temperature of $60^{\circ} \mathrm{C}$ and an optimal $\mathrm{pH}$ 7, from a water-poor mud. Subsequent molecular identification revealed homology to the species G. stearothermophilus. Our laboratory culturing experiments demonstrated the ability of G. stearothermophilus GF16 to grow in the presence of arsenate in a range of concentrations comparable to those of bacteria classified as arsenic resistant and in agreement with the natural environmental setting composition as well. This study highlights the adaptation capabilities of the new isolate of G. stearothermophilus and its tolerance to extreme environmental conditions and points out to further molecular and physiological investigations to clarify its role in the biogeochemical cycle of arsenic as well as its potential for the management of heavy-metal environmental contaminations.

Author Contributions: Data curation, R.P.; investigation, R.P., G.G., M.P., A.M., S.B., and G.F.; methodology, R.P., G.G., M.P., A.M., and G.F.; supervision, D.L., P.C., M.P., S.B., and G.F.; writing-review and editing, M.P. and G.F. All authors have read and agree to the published version of the manuscript.

Funding: This research was supported in part by the grant PRIN 2017: GoodbyWaste: Obtain GOOD-exploit BY-products-reduce WASTE funded by MIUR (Ministero dell'Istruzione dell'Università e della Ricerca).

Acknowledgments: We thank Sergio Sorbo, from the Department of Biology of University of Naples Federico II, for the production and analysis of TEM images.

Conflicts of Interest: The authors declare no conflict of interest.

\section{References}

1. Mathew, B.B.; Singh, H.; Biju, G.; Krishnamurthy, N.B. Classification, Source, and Effect of Environmental Pollutants and Their Biodegradation. J. Environ. Pathol. Toxicol. Oncol. 2017, 36, 55-71. [CrossRef] [PubMed]

2. Rensing, C.; Rosen, B.P. Heavy Metals Cycle (Arsenic, Mercury, Selenium, others). In Encyclopedia of Microbiology, 3rd ed.; Schaechter, M., Ed.; Elsevier: Amsterdam, The Netherlands; Academic Press: San Diego, CA, USA, 2009; Volume 3, pp. 205-219. ISBN 9780123739445. [CrossRef]

3. Kadirvelu, K.; Thamaraiselvi, K.; Namasivayam, C. Removal of heavy metals from industrial wastewaters by adsorption onto activated carbon prepared from an agricultural solid waste. Bioresour. Technol. 2001, 76, 63-65. [CrossRef]

4. Cole, M.; Lindeque, P.; Halsband, C.; Galloway, T.S. Microplastics as contaminants in the marine environment: A review. Mar. Pollut. Bull. 2011, 62, 2588-2597. [CrossRef] [PubMed]

5. World Health Organization. WHO Human Health Risk Assessment Toolkit: Chemical Hazards. 2010. Available online: https://apps.who.int/iris/handle/10665/44458 (accessed on 14 April 2020).

6. International Agency for Research on Cancer. International Agency for Research on Cancer Iarc Monographs on the Evaluation of Carcinogenic Risks to Humans. In Iarc Monographs on the Evaluation of Carcinogenic Risks to Humans; 2002; Available online: https://monographs.iarc.fr/list-of-classifications (accessed on 14 April 2020).

7. IARC Working Group on the Evaluation of Carcinogenic Risks to Humans. Arsenic, metals, fibres, and dusts. In A Review of Human Carcinogens; The International Agency for Research on Cancer: Lyon, France, 2012; ISBN 978-92-832-1320-8. 
8. Mamtani, R.; Stern, P.; Dawood, I.; Cheema, S. Metals and disease: A global primary health care perspective. J. Toxicol. 2011, 2011,1-11. [CrossRef]

9. Gillispie, E.C.; Sowers, T.D.; Duckworth, O.W.; Polizzotto, M.L. Soil Pollution Due to Irrigation with Arsenic-Contaminated Groundwater: Current State of Science. Curr. Pollut. Rep. 2015, 1, 1-12. [CrossRef]

10. Waseem, A.; Arshad, J.; Iqbal, F.; Sajjad, A.; Mehmood, Z.; Murtaza, G. Pollution Status of Pakistan: A Retrospective Review on Heavy Metal Contamination of Water, Soil, and Vegetables. BioMed Res. Int. 2014, 2014, 1-29. [CrossRef]

11. Gunduz, O.; Simsek, C.; Hasozbek, A. Arsenic pollution in the groundwater of Simav Plain, Turkey: Its impact on water quality and human health. Water Air Soil Pollut. 2010, 205, 43-62. [CrossRef]

12. Bartolucci, S.; Contursi, P.; Fiorentino, G.; Limauro, D.; Pedone, E. Responding to toxic compounds: A genomic and functional overview of Archaea. Front. Biosci. 2013, 18, 165-189. [CrossRef]

13. Oremland, R.S.; Stolz, J.F. The ecology of arsenic. Science 2003, 300, 939-944. [CrossRef]

14. Kulp, T.R.; Hoeft, S.E.; Asao, M.; Madigan, M.T.; Hollibaugh, J.T.; Fisher, J.C.; Stolz, J.F.; Culbertson, C.W.; Miller, L.G.; Oremland, R.S. Arsenic(III) fuels anoxygenic photosynthesis in hot spring biofilms from Mono Lake, California. Science 2008, 321,967-970. [CrossRef]

15. Pedone, E.; Bartolucci, S.; Fiorentino, G. Sensing and adapting to environmental stress: The archaeal tactic. Front. Biosci. A J. Virtual Libr. 2004, 9, 2909-2926. [CrossRef] [PubMed]

16. Mukhopadhyay, R.; Rosen, B.P.; Phung, L.T.; Silver, S. Microbial arsenic: From geocycles to genes and enzymes. FEMS Microbiol. Rev. 2002, 26, 311-325. [CrossRef] [PubMed]

17. Rosen, B.P. Bacterial resistance to heavy metals and metalloids. J. Biol. Inorg. Chem. 1996, 1, $273-277$. [CrossRef]

18. Saltikov, C.W.; Olson, B.H. Homology of Escherichia coli R773 arsA, arsB, and arsC genes in arsenic-resistant bacteria isolated from raw sewage and arsenic-enriched creek waters. Appl. Environ. Microbiol. 2002, 68, 280-288. [CrossRef]

19. Ji, G.; Silver, S. Regulation and expression of the arsenic resistance operon from Staphylococcus aureus plasmid pI258. J. Bacteriol. 1992, 164, 3684-3694. [CrossRef] [PubMed]

20. Antonucci, I.; Gallo, G.; Limauro, D.; Contursi, P.; Ribeiro, A.L.; Blesa, A.; Berenguer, J.; Bartolucci, S.; Fiorentino, G. An ArsR/SmtB family member regulates arsenic resistance genes unusually arranged in Thermus thermophilus HB27. Microb. Biotechnol. 2017, 10, 1690-1701. [CrossRef] [PubMed]

21. Gallo, G.; Antonucci, I.; Pirone, L.; Amoresano, A.; Contursi, P.; Limauro, D.; Pedone, E.; Bartolucci, S.; Fiorentino, G. A physicochemical investigation on the metal binding properties of $\mathrm{TtSmtB}$, a thermophilic member of the ArsR/SmtB transcription factor family. Int. J. Biol. Macromol. 2019, 138, 1056-1063. [CrossRef]

22. Fernández, M.; Morel, B.; Ramos, J.L.; Krell, T. Paralogous regulators ArsR1 and ArsR2 of Pseudomonas putida KT2440 as a basis for arsenic biosensor development. Appl. Environ. Microbiol. 2016, 82, 4133-4144. [CrossRef]

23. Patel, P.C.; Goulhen, F.; Boothman, C.; Gault, A.G.; Charnock, J.M.; Kalia, K.; Lloyd, J.R. Arsenate detoxification in a Pseudomonad hypertolerant to arsenic. Arch. Microbiol. 2007, 187, 171-183. [CrossRef]

24. Del Giudice, I.; Limauro, D.; Pedone, E.; Bartolucci, S.; Fiorentino, G. A novel arsenate reductase from the bacterium Thermus thermophilus HB27: Its role in arsenic detoxification. Biochim. Biophys. Acta Proteins Proteom. 2013, 1834, 2071-2079. [CrossRef]

25. Politi, J.; Spadavecchia, J.; Fiorentino, G.; Antonucci, I.; Casale, S.; De Stefano, L. Interaction of Thermus thermophilus ArsC enzyme and gold nanoparticles naked-eye assays speciation between As(III) and As(V). Nanotechnology 2015, 26, 435703. [CrossRef] [PubMed]

26. Politi, J.; Spadavecchia, J.; Fiorentino, G.; Antonucci, I.; De Stefano, L. Arsenate reductase from Thermus thermophilus conjugated to polyethylene glycol-stabilized gold nanospheres allow trace sensing and speciation of arsenic ions. J. R. Soc. Interface 2016, 13, 20160629. [CrossRef] [PubMed]

27. Wang, P.P.; Bao, P.; Sun, G.X. Identification and catalytic residues of the arsenite methyltransferase from a sulfate-reducing bacterium, Clostridium sp. BXM. FEMS Microbiol. Lett. 2015, 362, 1-8. [CrossRef] [PubMed]

28. Antonucci, I.; Gallo, G.; Limauro, D.; Contursi, P.; Ribeiro, A.L.; Blesa, A.; Berenguer, J.; Bartolucci, S.; Fiorentino, G. Characterization of a promiscuous cadmium and arsenic resistance mechanism in Thermus thermophilus HB27 and potential application of a novel bioreporter system. Microb. Cell Factories 2018, 17, 1-9. [CrossRef] 
29. Dhankher, O.P.; Shasti, N.A.; Rosen, B.P.; Fuhrmann, M.; Meagher, R.B. Increased cadmium tolerance and accumulation by plants expressing bacterial arsenate reductase. New Phytol. 2003, 159, 431-441. [CrossRef]

30. Xu, C.; Rosen, B.P. Metalloregulation of Soft Metal Resistance Pumps. In Metals and Genetics; Sarkar, B., Ed.; Springer: Boston, MA, USA, 1999; pp. 5-19. ISBN 978-1-4615-4723-5. [CrossRef]

31. Abbas, S.Z.; Rafatullah, M.; Hossain, K.; Ismail, N.; Tajarudin, H.A.; Abdul Khalil, H.P.S. A review on mechanism and future perspectives of cadmium-resistant bacteria. Int. J. Environ. Sci. Technol. 2018, 15, 243-262. [CrossRef]

32. Sabadell, J.E.; Axtmann, R.C. Heavy metal contamination from geothermal sources. Environ. Health Perspect. 1975, 12, 1-7. [CrossRef] [PubMed]

33. Nriagu, J.O. A global assessment of natural sources of atmospheric trace metals. Nature 1989, 338, 47-49. [CrossRef]

34. Hawkes, R.B.; Franzmann, P.D.; Plumb, J.J. Moderate thermophiles including "Ferroplasma cupricumulans" sp. nov. dominate an industrial-scale chalcocite heap bioleaching operation. Hydrometallurgy 2006, 83, 229-236. [CrossRef]

35. Özdemir, S.; Kilinc, E.; Poli, A.; Nicolaus, B.; Güven, K. Biosorption of Cd, Cu, Ni, Mn and Zn from aqueous solutions by thermophilic bacteria, Geobacillus toebii sub.sp. decanicus and Geobacillus thermoleovorans sub.sp. stromboliensis: Equilibrium, kinetic and thermodynamic studies. Chem. Eng. J. 2009, 152, 195-206. [CrossRef]

36. Gallo, G.; Puopolo, R.; Limauro, D.; Bartolucci, S.; Fiorentino, G. Metal-Tolerant Thermophiles: From the Analysis of Resistance Mechanisms to their Biotechnological Exploitation. Open Biochem. J. 2018, 12, 149-160. [CrossRef]

37. Poli, A.; Salerno, A.; Laezza, G.; di Donato, P.; Dumontet, S.; Nicolaus, B. Heavy metal resistance of some thermophiles: Potential use of $\alpha$-amylase from Anoxybacillus amylolyticus as a microbial enzymatic bioassay. Res. Microbiol. 2009, 160, 99-106. [CrossRef] [PubMed]

38. Chatterjee, S.K.; Bhattacharjee, I.; Chandra, G. Biosorption of heavy metals from industrial waste water by Geobacillus thermodenitrificans. J. Hazard. Mater. 2010, 175, 117-125. [CrossRef] [PubMed]

39. Piochi, M.; Mormone, A.; Strauss, H.; Balassone, G. The acid sulfate zone and the mineral alteration styles of the Roman Puteoli (Neapolitan area, Italy): Clues on fluid fracturing progression at the Campi Flegrei volcano. Solid Earth 2019, 10, 1809-1831. [CrossRef]

40. Valentino, G.M.; Cortecci, G.; Franco, E.; Stanzione, D. Chemical and isotopic compositions of minerals and waters from the Campi Flegrei volcanic system, Naples, Italy. J. Volcanol. Geotherm. Res. 1999, 91, 329-344. [CrossRef]

41. Piochi, M.; Mormone, A.; Balassone, G.; Strauss, H.; Troise, C.; De Natale, G. Native sulfur, sulfates and sulfides from the active Campi Flegrei volcano (southern Italy): Genetic environments and degassing dynamics revealed by mineralogy and isotope geochemistry. J. Volcanol. Geotherm. Res. 2015, 304, 180-193. [CrossRef]

42. Macwilliams, M.P.; Liao, M. Luria Broth (LB) and Luria Agar (LA) Media and Their Uses Protocol. 2006. Available online: https://www.asm.org/Protocols/Luria-Broth-LB-and-Luria-Agar-LA-Media-and-Their-U (accessed on 14 April 2020).

43. Schumann, P.; Pukall, R. The discriminatory power of ribotyping as automatable technique for differentiation of bacteria. Syst. Appl. Microbiol. 2013, 36, 369-375. [CrossRef]

44. Schumann, P.; Maier, T. MALDI-TOF mass spectrometry applied to classification and identification of bacteria. Methods Microbiol. 2014, 41, 275-306. [CrossRef]

45. Madeira, F.; Park, Y.M.; Lee, J.; Buso, N.; Gur, T.; Madhusoodanan, N.; Basutkar, P.; Tivey, A.R.N.; Potter, S.C.; Finn, R.D.; et al. The EMBL-EBI search and sequence analysis tools APIs in 2019. Nucleic Acids Res. 2019, 47, W636-W641. [CrossRef]

46. Rankin, I.D. MIC Testing. In Manual of Antimicrobial Susceptibility Testing; Coyle, M.B., Ed.; American Society for Microbiology: Washington, DC, USA, 2005; pp. 53-62. ISBN 1-55581-349-6.

47. Simeonova, D.D.; Lièvremont, D.; Lagarde, F.; Muller, D.A.E.; Groudeva, V.I.; Lett, M.C. Microplate screening assay for the detection of arsenite-oxidizing and arsenate-reducing bacteria. FEMS Microbiol. Lett. 2004, 237, 249-253. [CrossRef] 
48. Pinho, S.C.; Nunes, O.C.; Lobo-da-Cunha, A.; Almeida, M.F. Inactivation of Geobacillus stearothermophilus spores by alkaline hydrolysis applied to medical waste treatment. J. Environ. Manag. 2015, 161, 51-56. [CrossRef] [PubMed]

49. Giggenbach, W.F. Geothermal solute equilibria. Derivation of Na-K-Mg-Ca geoindicators. Geochim. Cosmochim. Acta 1988, 52, 2749-2765. [CrossRef]

50. Hedenquist, J.W.; Lowenstern, J.B. The role of magmas in the formation of hydrothermal ore deposits. Nature 1994, 370, 519-527. [CrossRef]

51. Ellis, A.J.; Mahon, W.A.J. Chemistry and Geothermal Systems; Academic Press: New York, NY, USA; San Francisco, CA, USA; London, UK, 1977; p. 392. ISBN 0122374509. [CrossRef]

52. Webster, J.G.; Nordstrom, D.K. Chapter 4: Geothermal Arsenic. The source, transport and fate of arsenic in geothermal systems. In Arsenic in Ground Water; Welch, A.H., Stollenwerk, K.G., Eds.; Springer: Boston, MA, USA, 2003; pp. 101-125. ISBN 978-0-306-47956-4. [CrossRef]

53. Farnfield, H.R.; Marcilla, A.L.; Ward, N.I. Arsenic speciation and trace element analysis of the volcanic río Agrio and the geothermal waters of Copahue, Argentina. Sci. Total. Environ. 2012, 433, 371-378. [CrossRef] [PubMed]

54. Aiuppa, A.; Avino, R.; Brusca, L.; Caliro, S.; Chiodini, G.; D’Alessandro, W.; Favara, R.; Federico, C.; Ginevra, W.; Inguaggiato, S.; et al. Mineral control of arsenic content in thermal waters from volcano-hosted hydrothermal systems: Insights from island of Ischia and Phlegrean Fields (Campanian Volcanic Province, Italy). Chem. Geol. 2006, 229, 313-330. [CrossRef]

55. Cardellini, C.; Chiodini, G.; Frondini, F.; Avino, R.; Bagnato, E.; Caliro, S.; Lelli, M.; Rosiello, A. Monitoring diffuse volcanic degassing during volcanic unrests: The case of Campi Flegrei (Italy). Sci. Rep. 2017, 7, 1-15. [CrossRef]

56. Valentino, G.M.; Stanzione, D. Source processes of the thermal waters from the Phlegraean Fields (Naples, Italy) by means of the study of selected minor and trace elements distribution. Chem. Geol. 2003, 194, 245-274. [CrossRef]

57. Nazina, T.N.; Tourova, T.P.; Poltaraus, A.B.; Novikova, E.V.; Grigoryan, A.A.; Ivanova, A.E.; Lysenko, A.M.; Petrunyaka, V.V.; Osipov, G.A.; Belyaev, S.S.; et al. Taxonomic study of aerobic thermophilic bacilli: Descriptions of Geobacillus subterraneus gen. nov., sp. nov. and Geobacillus uzenensis sp. nov. from petroleum reservoirs and transfer of Bacillus stearothermophilus, Bacillus thermocatenulatus, Bacillus th. Int. J. Syst. Evol. Microbiol. 2001, 51, 433-446. [CrossRef]

58. Kananavičiute, R.; Čitavičius, D. Genetic engineering of Geobacillus spp. J. Microbiol. Methods 2015, 111, 31-39. [CrossRef]

59. Suzuki, H. Peculiarities and biotechnological potential of environmental adaptation by Geobacillus species. Appl. Microbiol. Biotechnol. 2018, 102, 10425-10437. [CrossRef]

60. Burgess, S.A.; Flint, S.H.; Lindsay, D.; Cox, M.P.; Biggs, P.J. Insights into the Geobacillus stearothermophilus species based on phylogenomic principles. BMC Microbiol. 2017, 17, 140. [CrossRef]

61. Kliem, M.; Sauer, S. The essence on mass spectrometry based microbial diagnostics. Curr. Opin. Microbiol. 2012, 15, 397-402. [CrossRef]

62. Majumder, A.; Bhattacharyya, K.; Bhattacharyya, S.; Kole, S.C. Arsenic-tolerant, arsenite-oxidising bacterial strains in the contaminated soils of West Bengal, India. Sci. Total. Environ. 2013, 463-464, 1006-1014. [CrossRef] [PubMed]

63. Das, S.; Jean, J.S.; Kar, S.; Chou, M.L.; Chen, C.Y. Screening of plant growth-promoting traits in arsenic-resistant bacteria isolated from agricultural soil and their potential implication for arsenic bioremediation. J. Hazard. Mater. 2014, 272, 112-120. [CrossRef] [PubMed]

64. Cuebas, M.; Sannino, D.; Bini, E. Isolation and characterization of arsenic resistant Geobacillus kaustophilus strain from geothermal soils. J. Basic Microbiol. 2011, 51, 364-371. [CrossRef] [PubMed]

65. Yang, H.C.; Fu, H.L.; Lin, Y.F.; Rosen, B.P. Pathways of Arsenic Uptake and Efflux. Curr. Top. Membr. 2012, 69, 325-358. [CrossRef]

66. Cai, L.; Liu, G.; Rensing, C.; Wang, G. Genes involved in arsenic transformation and resistance associated with different levels of arsenic-contaminated soils. BMC Microbiol. 2009, 9, 4. [CrossRef]

67. Lebrun, E.; Brugna, M.; Baymann, F.; Muller, D.; Lièvremont, D.; Lett, M.C.; Nitschke, W. Arsenite oxidase, an ancient bioenergetic enzyme. Mol. Biol. Evol. 2003, 20, 686-693. [CrossRef] 
68. Dangayach, S.; Sharma, P.; Singhai, P.; Gupta, N. Microbial removal of arsenic: Mechanisms and Applications. Asian J. Multidisciplanary Stud. 2014, 2, 159-170.

69. Rosen, B.P. Families of arsenic transporters. Trends Microbiol. 1999, 7, 207-212. [CrossRef]

70. Yang, H.C.; Cheng, J.; Finan, T.M.; Rosen, B.P.; Bhattacharjee, H. Novel pathway for arsenic detoxification in the legume symbiont Sinorhizobium meliloti. J. Bacteriol. 2005, 187, 6991-6997. [CrossRef] [PubMed]

71. Hetzer, A.; Daughney, C.J.; Morgan, H.W. Cadmium ion biosorption by the thermophilic bacteria Geobacillus stearothermophilus and G. thermocatenulatus. Appl. Environ. Microbiol. 2006, 72, 4020-4027. [CrossRef] [PubMed]

72. Ranawat, P.; Rawat, S. Metal-tolerant thermophiles: Metals as electron donors and acceptors, toxicity, tolerance and industrial applications. Environ. Sci. Pollut. Res. 2017, 25, 4105-4133. [CrossRef]

73. Özdemir, S.; Klnç, E.; Poli, A.; Nicolaus, B. Biosorption of heavy metals (Cd2+, Cu2+, Co 2+, and Mn2+) by thermophilic bacteria, geobacillus thermantarcticus and anoxybacillus amylolyticus: Equilibrium and kinetic studies. Bioremediation J. 2013, 17, 86-96. [CrossRef]

74. Wu, D.; Zhang, Z.; Gao, Q.; Ma, Y. Isolation and characterization of aerobic, culturable, arsenic-tolerant bacteria from lead-zinc mine tailing in southern China. World J. Microbiol. Biotechnol. 2018, 34, 177. [CrossRef] [PubMed]

75. Krumova, K.; Nikolovska, M.; Groudeva, V. Isolation and identification of arsenic-transforming bacteria from arsenic contaminated sites in Bulgaria. Biotechnol. Biotechnol. Equip. 2008, 22, 721-728. [CrossRef]

76. Krumova, K.; Nikolovska, M.; Groudeva, V. Characterization of arsenic-transforming bacteria from arsenic contaminated sites in Bulgaria. Biotechnol. Biotechnol. Equip 2008, 22, 729-735. [CrossRef]

77. Egan, K.; Kelleher, P.; Field, D.; Rea, M.C.; Paul Ross, R.; Cotter, P.D.; Hilla, C. Genome sequence of Geobacillus stearothermophilus DSM 458, an antimicrobial-producing thermophilic bacterium, isolated from a sugar beet factory. Genome Announc. 2017, 5, 43. [CrossRef]

78. Koechler, S.; Arsène-Ploetze, F.; Brochier-Armanet, C.; Goulhen-Chollet, F.; Heinrich-Salmeron, A.; Jost, B.; Lièvremont, D.; Philipps, M.; Plewniak, F.; Bertin, P.N.; et al. Constitutive arsenite oxidase expression detected in arsenic-hypertolerant pseudomonas xanthomarina S11. Res. Microbiol. 2015, 166, 205-2014. [CrossRef]

79. Andres, J.; Bertin, P.N. The microbial genomics of arsenic. FEMS Microbiol. Rev. 2016, 40, 299-322. [CrossRef]

80. Chang, J.S.; Kim, Y.H.; Kim, K.W. The ars genotype characterization of arsenic-resistant bacteria from arsenic-contaminated gold-silver mines in the Republic of Korea. Appl. Microbiol. Biotechnol. 2008, 80, 155-165. [CrossRef] [PubMed] 